University of Nebraska - Lincoln

DigitalCommons@University of Nebraska - Lincoln

Faculty Papers and Publications in Animal

Science

Animal Science Department

2006

\title{
Effects of Growth-Promoting Agents and Season on Blood Metabolites and Body Temperature In Heifers
}

Terry L. Mader

University of Nebraska-Lincoln, tmader1@unl.edu

W. M. Kreikemeier

Alltech Biotechnology, Heartland Regional Office, Columbus, NE

Follow this and additional works at: https://digitalcommons.unl.edu/animalscifacpub

Part of the Animal Sciences Commons

Mader, Terry L. and Kreikemeier, W. M., "Effects of Growth-Promoting Agents and Season on Blood Metabolites and Body Temperature In Heifers" (2006). Faculty Papers and Publications in Animal Science. 611.

https://digitalcommons.unl.edu/animalscifacpub/611

This Article is brought to you for free and open access by the Animal Science Department at DigitalCommons@University of Nebraska - Lincoln. It has been accepted for inclusion in Faculty Papers and Publications in Animal Science by an authorized administrator of DigitalCommons@University of Nebraska - Lincoln. 


\title{
Effects of growth-promoting agents and season on blood metabolites and body temperature in heifers ${ }^{1,2}$
}

\author{
T. L. Mader*3 and W. M. Kreikemeier $\dagger$ \\ *Department of Animal Science, University of Nebraska, Concord 68728; and †Alltech Biotechnology, \\ Heartland Regional Office, Columbus, NE 68601
}

\begin{abstract}
To assess the efficacy of growth-promoting agents among seasons, triiodothyronine $\left(\mathrm{T}_{3}\right)$, thyroxine $\left(\mathrm{T}_{4}\right)$, plasma urea nitrogen (PUN), IGF-I, and tympanic temperature (TT) were measured in summer and winter studies. Heifers $(n=9 /$ pen $)$ were allotted to 12 pens in both December and June. Pens were assigned to 1 of 6 growth promotant treatments: control (no growth promotant), estrogenic implant (E), trenbolone acetate implant (TBA), E + TBA (ET), melengestrol acetate (MGA), and ET + MGA (ETM). Blood samples were collected from 4 heifers per pen per study on $\mathrm{d} 0$, 28,56 , and 84 via jugular puncture. Near the midpoint of both studies, TT were obtained from the heifers. There was a season by sample day interaction for all blood metabolites $(P<0.05)$. During the winter, IGF-I levels peaked on $\mathrm{d} 28$, whereas $\mathrm{T}_{3}, \mathrm{~T}_{4}$, and PUN peaked on $d 56$. In the summer, IGF-I levels increased from d 0 to 28 and remained elevated throughout the study.
\end{abstract}

Season by growth promotant interactions $(P<0.05)$ indicated that in the winter ET increased $\mathrm{T}_{3}$, whereas TBA alone decreased both $\mathrm{T}_{3}$ and $\mathrm{T}_{4}$, compared with control, or ET, and ETM treatment groups. Across seasons, treatments ET and ETM increased $(P<0.05)$ IGFI and decreased $(P<0.05)$ PUN. However, E, TBA, and MGA alone had no effect on IGF-I or PUN concentrations. The maximum TT was greater $(P<0.01)$ in the summer than in the winter, whereas the minimum TT was lower $(P<0.01)$ in the summer. Mean TT did not differ among growth-promoting treatments. However, in the summer and over both seasons, the maximum TT was lower $(P<0.05)$ in E-, MGA-, and ETM-treated heifers. Although limited growth promotant by season interactions existed, changes in blood metabolite levels resulting from the use of growth promotants do not appear to influence seasonal changes in body temperature as measured by TT.

Key words: anabolic steroid, body temperature, feedlot, heifer, season, serum hormone

(C2006 American Society of Animal Science. All rights reserved.

J. Anim. Sci. 2006. 84:1030-1037

\section{INTRODUCTION}

Extreme or rapid changes in environmental conditions can often be detrimental to cattle performance and well-being (Webster, 1973; Hahn, 1995). However, if climatic changes are not too abrupt, cattle can buffer effects of and adapt to changing environmental conditions through physiological and metabolic processes.

\footnotetext{
${ }^{1}$ A contribution of the University of Nebraska, Agricultural Research Division, Lincoln, NE 68583. Journal series no. 14854. Partial research support provided by the Biological and Environmental Research Program, US Dept. of Energy, through the Great Plains Regional Center of the National Institute for Global Environmental Change (NIGEC) under Cooperative Agreement No. DE-FCO390ER61010.

${ }^{2}$ The authors thank L. J. Spicer, Department of Animal Science, Oklahoma State University, Stillwater, for IGF-I analysis.

${ }^{3}$ Corresponding author: tmader@unlnotes.unl.edu

Received December 3, 2004.

Accepted November 8, 2005.
}

Kamal and Ibrahim (1969) reported that thyroid gland activity in summer was $16 \%$ less than in winter allowing for a decrease in metabolic rate and muscle activity to occur, and overall heat production to be reduced. In addition, when cattle were exposed to heat stress, blood urea nitrogen levels were found to decrease by $16 \%$ in lactating cows and by 28 to $30 \%$ in calves (Habeeb et al., 1992). The depression in blood urea nitrogen appears to be a result of resorption from the blood to the rumen to compensate for the decrease in ruminal ammonia-N due to reduced feed intake (Habeeb et al., 1992). When cattle are exposed to cold stress, gastrointestinal tract motility increases due to an elevated metabolic rate, resulting from an increase in thyroid hormone activity (Westra and Christopherson, 1976; Kennedy et al., 1977). Thus, feed intake is often enhanced in cattle exposed to cold environments (NRC, 1996).

There is evidence that estrogenic compounds also increase plasma concentration of thyroxine (Trenkle, 1997). In addition, when ruminants are administered 
anabolic agents, IGF-I concentrations are increased (Breier et al., 1988; Johnson et al., 1998). Change in body temperature, particularly when cattle are under environmental stress, is another physiological characteristic that could be influenced by anabolic agents. However, no data are available regarding effects of anabolic agents on body temperature. The objective of this experiment was to assess feedlot heifer responses to cold and heat exposure when administered growth promoting agents as determined by blood endocrine levels, plasma urea nitrogen (PUN), and tympanic temperature.

\section{MATERIALS AND METHODS}

The experiment was conducted at the University of Nebraska Haskell Agricultural Laboratory with the approval of the University of Nebraska-Lincoln Institutional Animal Care and Use Committee. Facility design and layout was reported by Mader et al. (1997). Facilities are located at $42^{\circ} 23^{\prime} \mathrm{N}$ latitude and $96^{\circ} 57^{\prime} \mathrm{W}$ longitude, with a mean elevation of $445 \mathrm{~m}$ above sea level. Details of the vaccination, parasite control, and diet regimens utilized for these experiments were reported by Kreikemeier and Mader (2004). Within a season, heifers had been stepped up to a $1.43 \mathrm{NEg}$ (Mcal/kg; DM basis) high-energy finishing diet at the beginning of each study. Heifers were fed Rumensin and Tylan (Elanco Animal Health, Indianapolis, IN) throughout the experimental feeding period. Diets were formulated to meet or exceed NRC (1996) nutrient requirements. Data reported herein were obtained from a subset of 540 heifers that were used in the experiment reported by Kreikemeier and Mader (2004). Experimental design, performance assessment procedures, and additional climate data were also reported by Kreikemeier and Mader (2004). Respective indicators of heat and cold stress were based on the temperature-humidity index (THI; Thom, 1959; NOAA, 1976) and the windchill index (WCI; US National Weather Service, 2005).

During a winter and a summer season, crossbred, nonpregnant Angus yearling heifers (108/season; mean initial BW $=382 \mathrm{~kg}$ ) were utilized for obtaining blood samples and tympanic temperatures (TT). In early December (winter season), and early June (summer season), heifers were stratified by BW and assigned randomly to 12 pens (9/pen per season). Six growth promotant treatments (2 pens of heifers/treatment per season) were imposed as follows: 1) control; 2) estrogenic implant [E, Compudose (24 mg of estradiol-17 $\beta$ ), Vetlife, West Des Moines, IA]; 3) androgenic implant [TBA, Finaplix-H (200 mg of trenbolone acetate), Intervet, Inc., Millsboro, DE]; 4) E + TBA (ET); 5) no implant and fed melengestrol acetate (MGA; Pharmacia and Upjohn, Kalamazoo, MI); and 6) ET implant and fed MGA (ETM). Cattle were fed over 104 and $105 \mathrm{~d}$ for the winter and summer feeding periods, respectively.

\section{Blood Collection and Assays}

For both seasons, blood samples were taken via jugular venipuncture and BW were obtained from the heifers (4 per pen) on d $0,28,56$, and 84 of treatment, beginning at 0800 and prior to being fed. For each heifer, blood $(10 \mathrm{~mL})$ for plasma was collected into tubes containing sodium heparin; blood $(5 \mathrm{~mL})$ was also collected for serum. After blood collection, the tubes were centrifuged $(1,380 \times g)$ for $10 \mathrm{~min}$. Plasma and serum fractions were isolated and stored frozen at $-20^{\circ} \mathrm{C}$ until analyzed.

Serum samples were analyzed for IGF-I concentrations using RIA, with acid-ethanol extraction (Echternkamp et al., 1990). The intra- and interassay CV for 3 IGF-I assays were 7.5 and $11.5 \%$, respectively. The sensitivity of the assay was defined as $95 \%$ of the total binding. Plasma concentrations of total thyroxine $\left(\mathbf{T}_{\mathbf{4}}\right)$ and triiodothyronine $\left(\mathbf{T}_{\mathbf{3}}\right)$ were quantified with solidphase RIA kits (Coat-A-Count, Diagnostic Products, Los Angeles, CA). Samples for $\mathrm{T}_{3}$ and $\mathrm{T}_{4}$ analysis were analyzed in separate assays. Duplicate analyses were performed on each sample for each hormone. The intraand interassay CV were 5.5 and $5.4 \%$, respectively, for $\mathrm{T}_{3}$, and 5.0 and $5.1 \%$, respectively, for $\mathrm{T}_{4}$. Plasma concentrations of urea-N were determined using procedures described by Marsh et al. (1965).

\section{Temperature Measures}

Tympanic temperatures were obtained from individual heifers (2 heifers/pen; 4 heifers/treatment per season) selected from the group of heifers from which blood was obtained. Tympanic temperatures were obtained during periods when the ambient temperature was predicted to be $<0^{\circ} \mathrm{C}$ in the winter and $>25^{\circ} \mathrm{C}$ in the summer. Tympanic temperatures were recorded using data loggers and thermistor cables (Stowaway, XTI; Onset Computer Corporation, Pocassatt, MA) based on procedures described by Mader et al. (2002) and Davis et al. (2003). Data loggers were secured in an ear of the heifer using self-adhesive bandages (Vet-Wrap; 3M Corporation, St. Paul, MN) and $2.25 \mathrm{~cm}$ of athletic tape (Andover Coded Products, Inc., Salisbury, MA). Tympanic temperature was read every $2 \mathrm{~min}$, with the average recorded every 15 min over 7 - and 5 -d periods for winter and summer, respectively. On d 28 of each study period, at the time of weighing, ear surface temperature was measured on 4 heifers from each pen using a Raynger $3 \mathrm{i}$ infrared gun (Raytek Corporation, Santa Cruz, CA).

\section{Statistical Analysis}

Data were analyzed using the Mixed Models procedures of SAS (SAS Inst., Inc., Cary, NC). Individual animal data were pooled by pen. The model for blood hormones and metabolites included season, growth promotant treatment, and sample day plus the 2- and 3way interactions. Performance data were analyzed within season with growth promotant treatment in- 
Table 1. Environmental conditions during periods for which tympanic temperatures were obtained in summer and winter, mean \pm SD

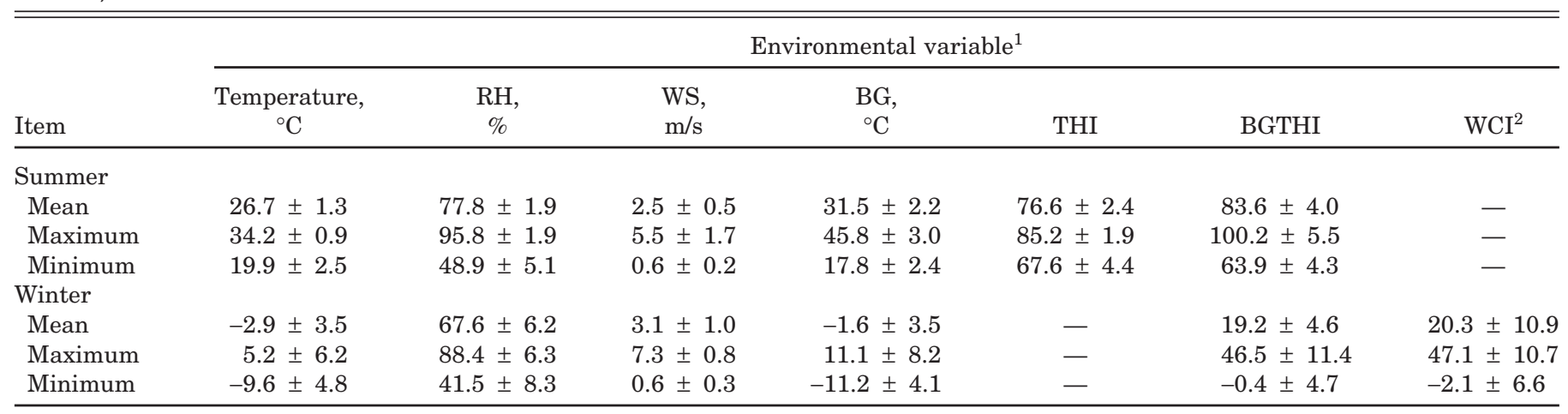

${ }^{1}$ Collected using a weather station located in the feeding facility; $\mathrm{RH}=$ relative humidity, $\mathrm{WS}=$ wind speed, $\mathrm{BG}=$ black globe temperature, THI $=$ temperature-humidity index, BGTHI $=$ THI using black globe temperature. THI $=(0.8 \times$ temperature $)+[(\mathrm{RH} / 100) \times($ temperature $14.4)]+46.4$.

${ }^{2} \mathrm{WCI}=\left(91.4-\left[0.475-\{0.0091 \times \mathrm{WS}\}+\left\{0.453 \times \mathrm{WS}^{-2}\right\}\right]\right) \times(109.178-\{\mathrm{T} / 1.8\})$, in which WS $=$ wind speed in $\mathrm{m} / \mathrm{s}$ and $\mathrm{T}=$ ambient temperature in ${ }^{\circ} \mathrm{C}$.

cluded in the model according to the procedures outlined by Kreikemeier and Mader (2004). Tympanic temperature and ear surface temperature were analyzed according to procedures outlined by Davis et al. (2003), and included season, growth promotant treatment, and the 2-way interaction in the model. The containment method was used to determine the degrees of freedom in the Mixed Models analysis. Least squares means were compared using an $F$-protected LSD $(P<0.05)$.

\section{RESULTS}

Climatic conditions during the 2 seasons were reported by Kreikemeier and Mader (2004). For the summer and winter periods during which TT were obtained, the ambient temperature averaged 26.7 and $-2.9^{\circ} \mathrm{C}$, respectively, and ranged from a daily average of 17.5 to $34.9^{\circ} \mathrm{C}$ for summer and -16.4 to $11.0^{\circ} \mathrm{C}$ for winter (Table 1). Mean THI was 76.6 with an average maximum of 85.2 for the summer, and a mean of 17.4 with an average minimum of 1.6 for the winter.

Based on the livestock safety index chart (LCI, 1970), heifers exposed to hot conditions were on the average in the alert category (THI > 74), but were also exposed to emergency category ( $\mathrm{THI}>83$ ) conditions, suggesting they were under heat stress during most of this period. During the winter, ambient temperatures averaged approximately $-3^{\circ} \mathrm{C}$ and were slightly above the normal of $-6^{\circ} \mathrm{C}$ (Mader et al., 1997). The lower than normal wind speed ( $3 \mathrm{vs.} 5 \mathrm{~m} / \mathrm{s}$ ) and relatively high WCI would suggest that environmental conditions during the winter were only moderately cold. The recorded wind speeds were approximately half of the normal wind speeds in both seasons due to shelter and shelterbelts located near the feedlot facilities. In general, environmental conditions during these studies were within normal ranges, with adverse but not particularly severe weather occurring during the course of both seasons (Kreikemeier and Mader, 2004).
Sample day by season interactions $(P<0.01)$ were found for all blood metabolites (Table 2). However, growth promotant by sample day and growth promotant by sample day by season interactions were not found. In general, IGF-I increased $(P<0.05)$ from d 0 to 28 in the winter and in the summer (Table 2). However, IGF-I levels declined $(P<0.05)$ after $\mathrm{d} 28$ to $\mathrm{d}$ 0 levels in the winter but remained near $d 28$ levels throughout the summer. Thyroid hormone levels $\left(\mathrm{T}_{3}\right.$ and $\mathrm{T}_{4}$ ) followed similar trends between seasons across sample days. As expected, $\mathrm{T}_{3}$ and $\mathrm{T}_{4}$ levels were elevated $(P<0.01)$ in the winter compared with the summer, but distinctly different trends were found between seasons from d 56 to 84 . By d 84, average ambient temperatures were declining in the summer; this was associated with increased thyroid hormone concentrations. The opposite was true for the winter study. On d 56, PUN was elevated in the winter and lower in the summer when compared with d 28 levels $(P<0.05)$; thus, PUN tended to peak around $d 56$ in the winter and $\mathrm{d} 28$ in the summer.

In the winter and summer, ET and ETM treatment groups had greater $(P<0.05)$ ADG than the control group (Table 3). Within a season, DMI were similar among growth promotant treatments. In both winter and summer, ET, MGA, and ETM treatment groups had greater $(P<0.05) \mathrm{G}: \mathrm{F}$ than the respective control groups. There was no growth-promoting agent by season interaction for serum IGF-I or PUN concentration (Table 3). Across both seasons, IGF-I was increased ( $P$ $<0.05)$ in ET- and ETM-treated heifers when compared with control heifers. There was a growth promotant by season interaction $(P<0.05)$ for $\mathrm{T}_{3}$ and $\mathrm{T}_{4}$ concentrations. In the winter, the ET-treated heifers had increased $(P<0.05) \mathrm{T}_{3}$ levels. Also in the winter, the ETM-treated heifers had increased $(P<0.05) \mathrm{T}_{4}$ levels, whereas TBA-treated heifers had decreased $(P<0.05)$ $\mathrm{T}_{3}$ and $\mathrm{T}_{4}$ when compared with control heifers. In the summer, MGA-treated heifers had greater $(P<0.05)$ 
Table 2. Effects of season and sample day on blood hormone and metabolite concentrations in feedlot heifers ${ }^{1}$

\begin{tabular}{|c|c|c|c|c|c|}
\hline \multirow[b]{2}{*}{ Item } & \multicolumn{4}{|c|}{ Day of blood collection ${ }^{2}$} & \multirow[b]{2}{*}{$\mathrm{SE}$} \\
\hline & 0 & 28 & 56 & 84 & \\
\hline \multicolumn{6}{|c|}{ IGF-I, ng/mL } \\
\hline Winter & $96.9^{\mathrm{a}}$ & $130.0^{\mathrm{b}}$ & $103.3^{\mathrm{a}}$ & $90.9^{\mathrm{a}}$ & 6.43 \\
\hline Summer & $60.6^{\mathrm{a}}$ & $104.5^{\mathrm{b}}$ & $95.0^{\mathrm{b}}$ & $108.5^{\mathrm{b}}$ & 6.43 \\
\hline \multicolumn{6}{|l|}{$\mathrm{T}_{3}, \mathrm{ng} / \mathrm{mL}$} \\
\hline Winter & $1.42^{\mathrm{a}}$ & $1.49^{\mathrm{a}}$ & $1.62^{\mathrm{b}}$ & $1.48^{\mathrm{a}}$ & 0.037 \\
\hline Summer & $1.19^{b}$ & $0.94^{\mathrm{a}}$ & $0.95^{\mathrm{a}}$ & $1.33^{\mathrm{c}}$ & 0.037 \\
\hline \multicolumn{6}{|l|}{$\mathrm{T}_{4}, \mathrm{ng} / \mathrm{mL}$} \\
\hline Winter & $66.3^{\mathrm{a}}$ & $68.1^{\mathrm{a}}$ & $77.9^{\mathrm{b}}$ & $69.0^{\mathrm{a}}$ & 1.77 \\
\hline Summer & $66.0^{\mathrm{bc}}$ & $53.4^{\mathrm{a}}$ & $63.2^{\mathrm{b}}$ & $69.5^{\mathrm{c}}$ & 1.77 \\
\hline \multicolumn{6}{|c|}{ PUN, mg/dL } \\
\hline Winter & $9.7^{\mathrm{a}}$ & $13.5^{\mathrm{b}}$ & $19.2^{\mathrm{c}}$ & $12.3^{\mathrm{b}}$ & 0.55 \\
\hline Summer & $13.7^{\mathrm{b}}$ & $17.6^{\mathrm{c}}$ & $13.1^{\mathrm{b}}$ & $11.6^{\mathrm{a}}$ & 0.55 \\
\hline
\end{tabular}

${ }^{\mathrm{a}-\mathrm{c}}$ Means within a row without a common superscript differ $(P<0.05)$.

${ }^{1}$ Means included control and growth-promotant treatment groups $(n=12) . T_{3}=$ triiodothyronine; $T_{4}=$ thyroxine; PUN = plasma urea nitrogen.

${ }^{2}$ Number of days of treatment. Day by season interaction $(P<0.01)$ for all metabolites.

Table 3. Effects of growth-promoting treatment and season on performance and blood hormone and metabolite concentrations in feedlot heifers ${ }^{1}$

\begin{tabular}{|c|c|c|c|c|c|c|c|}
\hline \multirow[b]{2}{*}{ Item } & \multicolumn{6}{|c|}{ Treatment $^{2}$} & \multirow[b]{2}{*}{$\mathrm{SE}$} \\
\hline & $\mathrm{C}$ & $\mathrm{E}$ & TBA & ET & MGA & ETM & \\
\hline \multicolumn{8}{|c|}{ Performance data } \\
\hline \multicolumn{8}{|c|}{$\mathrm{ADG}, \mathrm{kg}$} \\
\hline Winter & $1.33^{\mathrm{a}}$ & $1.40^{\mathrm{ab}}$ & $1.39^{\mathrm{ab}}$ & $1.49^{\mathrm{b}}$ & $1.41^{\mathrm{ab}}$ & $1.47^{\mathrm{b}}$ & 0.04 \\
\hline Summer & $1.16^{\mathrm{a}}$ & $1.26^{\mathrm{ab}}$ & $1.24^{\mathrm{a}}$ & $1.37^{\mathrm{b}}$ & $1.27^{\mathrm{ab}}$ & $1.37^{\mathrm{b}}$ & 0.04 \\
\hline \multicolumn{8}{|l|}{ DMI, kg } \\
\hline Winter & 10.81 & 10.86 & 10.78 & 10.92 & 10.42 & 10.50 & 0.17 \\
\hline Summer & 9.11 & 9.23 & 9.15 & 9.39 & 9.14 & 9.65 & 0.17 \\
\hline \multicolumn{8}{|l|}{$\mathrm{G}: \mathrm{F}$} \\
\hline Winter & $0.123^{\mathrm{a}}$ & $0.129^{\mathrm{ab}}$ & $0.129^{\mathrm{ab}}$ & $0.137^{\mathrm{bc}}$ & $0.135^{\mathrm{bc}}$ & $0.140^{\mathrm{c}}$ & 0.004 \\
\hline Summer & $0.127^{\mathrm{a}}$ & $0.137^{\mathrm{abc}}$ & $0.136^{\mathrm{ab}}$ & $0.147^{\mathrm{c}}$ & $0.139^{\mathrm{bc}}$ & $0.142^{\mathrm{bc}}$ & 0.004 \\
\hline \multicolumn{8}{|c|}{ Blood hormone/metabolite data } \\
\hline \multicolumn{8}{|c|}{ IGF-I, $\mathrm{ng} / \mathrm{mL}$} \\
\hline Winter & 94.3 & 109.9 & 102.2 & 116.8 & 91.5 & 117.1 & 7.88 \\
\hline Summer & 80.2 & 90.2 & 92.5 & 98.8 & 82.5 & 108.9 & 7.88 \\
\hline Mean & $87.2^{\mathrm{a}}$ & $100.1^{\mathrm{abc}}$ & $97.3^{\mathrm{ab}}$ & $107.8^{\mathrm{bc}}$ & $87.0^{\mathrm{a}}$ & $113.0^{\mathrm{c}}$ & 5.57 \\
\hline \multicolumn{8}{|l|}{$\mathrm{T}_{3},{ }^{3} \mathrm{ng} / \mathrm{mL}$} \\
\hline Winter & $1.51^{\mathrm{b}}$ & $1.46^{\mathrm{ab}}$ & $1.37^{\mathrm{a}}$ & $1.77^{\mathrm{c}}$ & $1.43^{\mathrm{ab}}$ & $1.50^{\mathrm{b}}$ & 0.045 \\
\hline Summer & $1.12^{\mathrm{ab}}$ & $1.19^{\mathrm{b}}$ & $1.14^{\mathrm{ab}}$ & $1.02^{\mathrm{a}}$ & $1.06^{\mathrm{a}}$ & $1.08^{\mathrm{ab}}$ & 0.045 \\
\hline Mean & 1.31 & 1.32 & 1.24 & 1.39 & 1.25 & 1.29 & 0.032 \\
\hline \multicolumn{8}{|l|}{$\mathrm{T}_{4},{ }^{3} \mathrm{ng} / \mathrm{mL}$} \\
\hline Winter & $70.6^{\mathrm{b}}$ & $70.6^{\mathrm{b}}$ & $63.9^{\mathrm{a}}$ & $70.9^{\mathrm{b}}$ & $67.7^{\mathrm{ab}}$ & $78.0^{\mathrm{c}}$ & 2.17 \\
\hline Summer & $58.4^{\mathrm{a}}$ & $63.0^{\mathrm{ab}}$ & $63.1^{\mathrm{ab}}$ & $62.6^{\mathrm{ab}}$ & $67.8^{\mathrm{b}}$ & $63.1^{\mathrm{ab}}$ & 2.17 \\
\hline Mean & 64.5 & 66.8 & 63.5 & 66.8 & 67.8 & 70.6 & 1.53 \\
\hline \multicolumn{8}{|c|}{ PUN, mg/dL } \\
\hline Winter & 13.8 & 14.9 & 13.0 & 12.2 & 15.1 & 13.0 & 0.68 \\
\hline Summer & 15.0 & 15.2 & 15.2 & 12.6 & 14.0 & 11.9 & 0.68 \\
\hline Mean & $14.4^{\mathrm{b}}$ & $15.0^{\mathrm{b}}$ & $14.1^{\mathrm{b}}$ & $12.4^{\mathrm{a}}$ & $14.6^{\mathrm{b}}$ & $12.4^{\mathrm{a}}$ & 0.48 \\
\hline
\end{tabular}

${ }^{\mathrm{a}-\mathrm{c}}$ Means within a row without a common superscript differ $(P<0.05)$.

${ }^{1}$ Means $\left(n=8 /\right.$ season). $T_{3}=$ triiodothyronine; $T_{4}=$ thyroxine; $P U N=$ plasma urea nitrogen. Means of pooled growth promotant treatment and season performance data have previously been reported (Kreikemeier and Mader, 2004). Season effects were found for ADG, DMI, G:F, IGF-I, $\mathrm{T}_{3}$, and $\mathrm{T}_{4},(P<0.05)$.

${ }^{2} \mathrm{C}=$ Control (no growth promotant), $\mathrm{E}=$ estrogenic implant, $\mathrm{TBA}=$ trenbolone acetate implant, $\mathrm{ET}=$ estrogenic + TBA, MGA = melengestrol acetate, $\mathrm{ETM}=\mathrm{E}+\mathrm{TBA}+\mathrm{MGA}$.

${ }^{3}$ Growth promotant by season interaction $(P<0.05)$. 
Table 4. Effects of season on ear surface temperature (EST) and tympanic temperature (TT) in feedlot heifers ${ }^{1}$

\begin{tabular}{lccc}
\hline \hline & \multicolumn{2}{c}{ Season } & \\
\cline { 2 - 3 } Item & Summer & Winter & SE \\
\hline EST, ${ }^{\circ} \mathrm{C}$ & $33.5^{\mathrm{b}}$ & $13.6^{\mathrm{a}}$ & 0.4 \\
$\mathrm{TT}$ & & & \\
Mean, ${ }^{\circ} \mathrm{C}$ & 39.0 & 38.9 & 0.3 \\
Maximum, ${ }^{\circ} \mathrm{C}$ & $40.0^{\mathrm{b}}$ & $39.4^{\mathrm{a}}$ & 0.1 \\
Minimum, ${ }^{\circ} \mathrm{C}$ & $37.9^{\mathrm{a}}$ & $38.4^{\mathrm{b}}$ & 0.1 \\
\hline
\end{tabular}

${ }^{\mathrm{a}, \mathrm{b}}$ Means within a row without a common superscript $\operatorname{differ}(P<$ 0.01).

${ }^{1}$ Means included control and growth promotant treatment groups. For EST, $\mathrm{n}=12 /$ season. For TT, $\mathrm{n}=72 /$ season.

$\mathrm{T}_{4}$ levels than control heifers. Across season, heifers receiving ET (ET and ETM treatments) had lower PUN levels.

Ear surface temperatures were 33.5 and $13.6^{\circ} \mathrm{C}(P<$ $0.01)$ respectively, for summer and winter (Table 4). The ear surface temperatures were recorded in the event that interactions of growth-promoting agent by season could be attributable to payout of the implant, although effects of ear temperature on blood flow in and around the implant site are unknown. Average TT was not different between seasons. When cattle were exposed to hot conditions in the summer, TT displayed a greater range than when cattle were exposed to cold conditions in the winter. Maximum TT was greater $(P$ $<0.01)$ and minimum TT was lower $(P<0.01)$ in the summer than in the winter. Analysis of hourly data (Figure 1) indicated that peak summer TT occurred around 1700 whereas peak winter TT were not as evident. Also, minimum summer TT were found at 0700 . Difference in TT between summer and winter were found at 0500, 0600, 0700, 0800, 1600, 1700, and 2100 with the diurnal TT pattern being less variable in the winter than in the summer.

There was a growth-promoting treatment by season interaction $(P<0.05)$ for ear surface temperature (Table $5)$. In the summer, there was no difference between ear surface temperatures across growth-promoting treatments. In the winter, the MGA-treated heifer had ear surface temperatures similar to control but lower $(P<$ 0.05) than groups receiving TBA, ET, and ETM.

Mean TT were similar among treatments within season. A growth promotant by season interaction was evident for average maximum TT $(P<0.05)$ and for average minimum TT $(P<0.07)$. Numerically, control heifer groups had greater maximum TT, particularly in the winter, with the MGA heifers having the lowest maximum TT in both seasons. The ET-treated cattle had greater $(P<0.05)$ maximum TT in the summer when compared with MGA-fed groups (MGA and ETM). However, in the winter, cattle receiving E or MGA, or both (E, ET, MGA, and ETM groups) had lower $(P<$ $0.05)$ maximum TT than did control cattle. Differences in minimum TT tended to be found only in the summer, with E-treated cattle having greater $(P<0.05)$ minimum TT than TBA and ETM treatment groups.

\section{DISCUSSION}

Over both seasons, the rise in IGF-I concentration from $\mathrm{d} 0$ to $\mathrm{d} 28$ ranged from $34.2 \%$ in the winter to $72.4 \%$ in the summer. After d 28, IGF-I concentrations returned to near d $0(96.9 \mathrm{ng} / \mathrm{mL})$ concentrations in the winter, but remained elevated above d $0(60.6 \mathrm{ng} / \mathrm{mL})$ concentrations during the summer, although mean IGF-I concentration from d 28 through d 84 were similar in winter $(108.1 \mathrm{ng} / \mathrm{mL})$ and summer $(102.7 \mathrm{ng} / \mathrm{mL})$. Dunn et al. (2003) reported increases in sera IGF-I concentrations of 52 and $84 \%$ because of using growthpromoting implants in steers. In that study, the 28-d gain response to implanting ranged from 0.52 to 0.97 $\mathrm{kg} / \mathrm{d}$. From this study, it appears that the early rapid gain response could be partially attributed to the rapid rise in IGF-I associated with the use of growth promotants, particularly ET combinations.

Hersom et al. (2004) found that IGF-I concentration is a function of the plane of nutrition. In that study, IGF-I blood concentrations were between 45 and $90 \mathrm{ng} /$ $\mathrm{mL}$ for cattle consuming native range, whereas cattle consuming greater quality wheat pasture had blood concentrations between 115 and $158 \mathrm{ng} / \mathrm{mL}$. Sarko et al. (1994) and Richards et al. (1995) also reported that IGF-I concentrations were positively correlated with feed intake. In the current study, heifers were provided lower energy diets before the start of the study. During that period they were being stepped up or adapted to the high-energy finishing diet. The increase in energy density of the diet in combination with the cattle being adapted to the diet likely contributed to a portion of the increase in IGF-I concentrations from d 0 to 28 , even in the control cattle group, which had an average increase to $12.9 \mathrm{ng} / \mathrm{mL}$ (data not shown) during this period. The overall effects of season on IGF-I concentration appears to be nonsignificant, particularly after cattle were on the finishing diet for $28 \mathrm{~d}$. However, growthpromoting implants had a significant influence on IGFI concentrations.

Stick et al. (1998) found that an increase in IGF-I was associated with an increase in ADG and improvements in feed efficiency. In the study reported herein, the greater IGF-I concentrations found in the ET- and ETM-treated heifers may be indicative of the greater $\mathrm{ADG}$ and G:F found in these same 2 groups when compared with control heifers. According to Florini et al. (1991), IGF-I is a somatotropin-dependent anabolic peptide that stimulates proliferation and differentiation of many cells including muscle cells. Previous studies indicated that implanting with an estrogenic compound increased circulating concentrations of somatotropin and IGF-I (Grigsby and Trenkle, 1986; Breier et al., 1988). However, TBA alone or in combination with $\mathrm{E}$ had no effect on somatotropin (Hunt et al., 1991; Hayden et al., 1992) whereas IGF-I levels were in- 


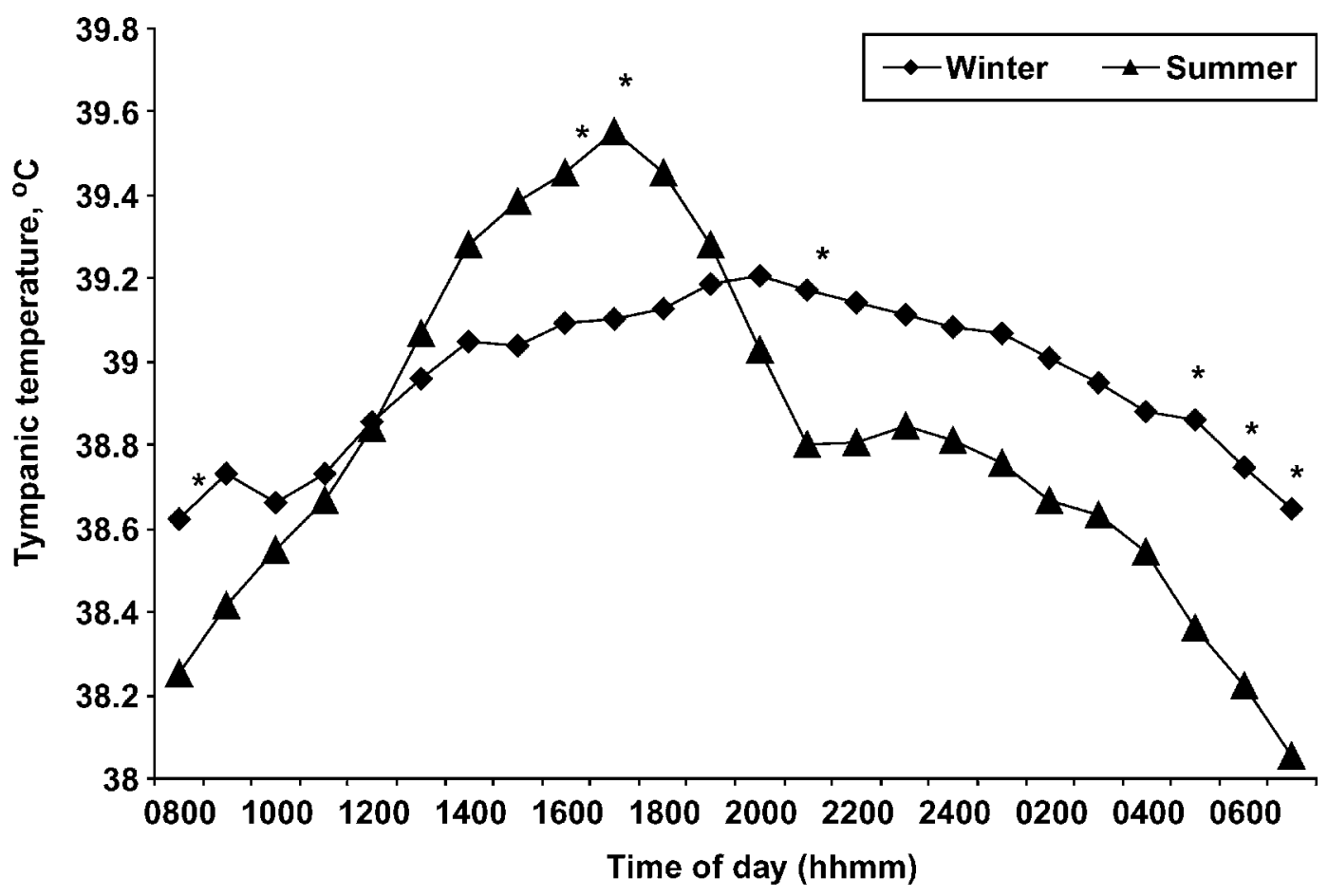

Figure 1. Effects of season on tympanic temperature over a 24-h period in feedlot heifers. *Means within an hour differ by season $(P<0.05 ; \mathrm{SE}=0.10)$. Each point represents the mean of 12 pens of cattle.

creased (Lee and Henricks, 1990; Hunt et al., 1991). Studies reported herein would support these findings, but suggest that an $\mathrm{E}+\mathrm{TBA}$ implant combination is more effective in elevating circulating IGF-I than single-product implants.
As expected, seasonal effects on $\mathrm{T}_{3}$ and $\mathrm{T}_{4}$ were apparent throughout this study and changed with changing environmental conditions. Yousef and Johnson (1985) reported greater thyroid gland activity under cold exposure, and, in contrast, thyroid gland activity declined

Table 5. Effect of growth promotant treatment and season on ear surface temperature (EST) and tympanic temperature (TT) in feedlot heifers

\begin{tabular}{|c|c|c|c|c|c|c|c|}
\hline \multirow[b]{2}{*}{ Item } & \multicolumn{7}{|c|}{ Treatment $^{1}$} \\
\hline & $\mathrm{C}$ & $\mathrm{E}$ & TBA & ET & MGA & ETM & $\mathrm{SE}$ \\
\hline \multicolumn{8}{|l|}{$\mathrm{EST},{ }^{\circ} \mathrm{C}$} \\
\hline Winter & $12.5^{\mathrm{ab}}$ & $13.1^{\mathrm{ab}}$ & $13.6^{\mathrm{b}}$ & $15.1^{\mathrm{bc}}$ & $10.6^{\mathrm{a}}$ & $16.8^{\mathrm{c}}$ & 1.0 \\
\hline Summer & 33.7 & 33.8 & 32.8 & 33.6 & 34.0 & 33.0 & 1.0 \\
\hline Mean & 23.1 & 23.5 & 23.2 & 24.4 & 22.3 & 24.9 & 0.6 \\
\hline \multicolumn{8}{|l|}{ Mean TT } \\
\hline Winter & 39.24 & 38.77 & 39.03 & 38.69 & 38.66 & 38.87 & 0.67 \\
\hline Summer & 38.97 & 39.03 & 38.94 & 39.70 & 39.36 & 38.75 & 0.67 \\
\hline Mean & 39.11 & 38.90 & 38.99 & 39.20 & 39.01 & 38.81 & 0.43 \\
\hline \multicolumn{8}{|c|}{ Maximum $\mathrm{TT},{ }^{2}{ }^{\circ} \mathrm{C}$} \\
\hline Winter & $40.08^{\mathrm{b}}$ & $39.25^{\mathrm{a}}$ & $39.52^{\mathrm{ab}}$ & $39.14^{\mathrm{a}}$ & $39.13^{\mathrm{a}}$ & $39.44^{\mathrm{a}}$ & 0.30 \\
\hline Summer & $40.23^{\mathrm{bc}}$ & $39.97^{\mathrm{abc}}$ & $40.18^{\mathrm{bc}}$ & $40.44^{\mathrm{c}}$ & $39.72^{\mathrm{a}}$ & $39.80^{\mathrm{ab}}$ & 0.30 \\
\hline Mean & $40.16^{\mathrm{b}}$ & $39.61^{\mathrm{a}}$ & $39.80^{\mathrm{ab}}$ & $39.79^{\mathrm{ab}}$ & $39.43^{\mathrm{a}}$ & $39.62^{\mathrm{a}}$ & 0.14 \\
\hline \multicolumn{8}{|c|}{ Minimum $\mathrm{TT},{ }^{2}{ }^{\circ} \mathrm{C}$} \\
\hline Winter & 38.40 & 38.32 & 38.46 & 38.32 & 38.19 & 38.48 & 0.27 \\
\hline Summer & $37.69^{\mathrm{d}}$ & $38.32^{\mathrm{e}}$ & $37.68^{\mathrm{d}}$ & $37.95^{\mathrm{de}}$ & $38.02^{\text {de }}$ & $37.62^{\mathrm{d}}$ & 0.27 \\
\hline Mean & 38.05 & 38.32 & 38.07 & 38.14 & 38.11 & 38.05 & 0.12 \\
\hline
\end{tabular}

${ }^{\mathrm{a}-\mathrm{c}}$ Means within a row without a common superscript differ $(P<0.05)$.

${ }^{\mathrm{d}, \mathrm{e}}$ Means within a row without a common superscript differ $(P<0.10)$.

${ }^{1} \mathrm{C}=$ Control (no growth promotant), $\mathrm{E}=$ estrogenic implant, TBA = trenbolone acetate implant, $\mathrm{ET}=$ estrogenic + TBA, MGA = melengestrol acetate, ETM = E + TBA + MGA. For EST, n = 2/season. For TT, mean $\mathrm{n}=6 /$ season.

${ }^{2}$ Growth promotant by season interaction $(P<0.10)$. 
when cattle were exposed to heat stress (Kamal and Ibrahim, 1969; Habeeb et al., 1992).

Thyroid activity influences digesta passage rate and digestibility in ruminants (Christopherson, 1985). Thyroid gland responses are also influenced by level of feed intake (Yousef and Johnson, 1985). Positive relationships have been found between thyroid hormone concentrations and energy balance (Murphy and Loerch, 1994; Hersom et al., 2004). Based on seasonal differences in DMI in the current study, thyroid activity would appear to be influencing DMI more than DMI influencing thyroid activity. In addition, in this study, the ET and ETM combination appeared to enhance the normal thyroid responses (ET increased $\mathrm{T}_{3}$ and ETM increased $\mathrm{T}_{4}$ ) that are found with declining environmental temperature in the winter. However, opposite shifts in $\mathrm{T}_{3}$ and $\mathrm{T}_{4}$ concentration were not observed in the summer in these treatment groups.

Overall, seasonal effects were not found for PUN concentrations. However, peak PUN concentrations were found on d 56 in the winter and d 28 in the summer. In the winter, during the period when ambient temperatures declined and approached winter lows, feed intake was stimulated and was associated with greater PUN levels than were found on $\mathrm{d} 56$. In the summer, ambient temperature would be peaking around $d 56$, thus suppressing feed intake and contributing to a lower PUN. Similarly, a $16 \%$ decline in PUN in the summer compared with winter-fed ruminants was reported previously (Habeeb et al., 1992). Habeeb et al. (1992) stated that this decline in summer PUN levels could be due to the decrease in DMI, thereby lowering ruminal nitrogen recycling, and causing resorption of nitrogen into the rumen from the blood. Kreikemeier and Mader (2004) reported the greatest and lowest DMI during d 36 to 69 in the winter and summer studies, respectively.

Growth-promoting treatments were found to affect PUN concentrations. Over the entire experiment, heifers that had greater IGF-I concentrations (ET and ETM treatment groups) also had lower PUN concentrations. Changes in PUN concentrations could be attributed to increased protein synthesis, decreased protein degradation, or a combination of both. However, in this study, changes in weather patterns within a season tended to result in greater changes in PUN than the use of growth promotants.

These data suggest that, at least in the winter, implanting can elevate ear surface temperatures as much as $6^{\circ} \mathrm{C}$; however, overall ear surface temperatures in the winter are less than one-half of temperatures found in the summer. Ear surface temperature is likely influenced by both core body and external ambient temperatures. The data also indicate that when cattle get hot in the summer, they tend to compensate at night by ridding the body of heat in preparation for subsequent heat episodes. Thus, the range in TT will be greater in the summer. The lower nighttime TT enabled cattle to prepare for the heat of the day; whereas greater overall TT in the winter buffers the animal against cold threats.
Very few relationships were found between TT and blood metabolites. In the summer, the E-treated heifers had a greater minimum TT; the same heifers had greater $\mathrm{T}_{3}$ than heifers receiving ET and MGA treatments. Also in the summer, the MGA-treated heifers had the lowest maximum TT; however, when compared with control heifers, they had greater $\mathrm{T}_{4}$ concentrations.

The lower maximum TT found in the MGA treatment group would be supportive of conclusions made by Busby and Loy (1996); they reported that heifers fed MGA were less likely to die from heat stress than heifers not fed MGA. The greater minimum TT found in the E-treated group in the summer would suggest that E-implanted cattle might be more susceptible to heat stress. Even though the growth-promoting response of $\mathrm{E}$ and MGA are mediated through estrogen receptors, effects on minimum TT were the opposite. The estrussuppressing effects of MGA might be responsible for any lowering of TT and heat-related death loss as suggested by Busby and Loy (1996). Also, heifers assigned to the aggressive implant treatment (ET) had greater maximum TT in the summer than did MGA-treated heifers. These effects could influence cattle well-being under extreme environmental conditions, particularly in the summer. However, in the winter, growth promotants generally lowered winter maximum TT but had no effect on minimum TT when compared with control cattle TT.

Based on these data, relative differences in cattle performance due to growth promotants would likely be similar between winter and summer feeding periods and not significantly altered by seasonal influences on blood hormone levels. Changes in environmental conditions clearly elicit changes in animal thyroid activity, whereas the combined use of growth promotants influences IGF-I and PUN concentrations. Differences in measures of body temperature were observed among growth-promoting treatments; however, more pronounced differences were found between summer and winter diurnal temperature patterns than among growth promotant-treated cattle.

\section{LITERATURE CITED}

Breier, B. H., P. D. Gluckman, and J. J. Bass. 1988. Influence of nutritional status and oestradiol-17 $\beta$ on plasma growth hormone, insulin-like growth factors-I and II and the response to exogenous growth hormone in young steers. J. Endocrinol. 118:243-250.

Busby, D., and D. Loy. 1996. Heat stress in feedlot cattle: Producer survey results. Iowa Agric. Exp. Stn., A. S. Leaflet R1348. Iowa State Univ., Ames.

Christopherson, R. J. 1985. Endocrine systems and thermal environment. Pages 163-180 in Stress Physiology in Livestock: Basic Principles. CRC Press Inc., Boca Raton, FL.

Davis, M. S., T. L. Mader, S. M. Holt, and A. M. Parkhurst. 2003. Strategies to reduce feedlot cattle heat stress: Effects on tympanic temperature. J. Anim. Sci. 81:649-661.

Dunn, J. D., B. J. Johnson, J. P. Kayser, A. T. Waylan, E. K. Sissom, and J. S. Drouilland. 2003. Effects of flax supplementation and a combined trenbolone acetate and estradiol implant on circulating insulin-like growth factor-I and muscle insulin-like growth 
factor-I messenger RNA levels in beef cattle. J. Anim. Sci. 81:3028-3034.

Echternkamp, S. E., L. J. Spicer, K. E. Gregory, S. F. Canning, and J. M. Hammond. 1990. Concentrations of insulin-like growth factor I in blood and ovarian follicular fluid of cattle selected for twins. Biol. Reprod. 43:8-14.

Florini, J. R., D. Z. Ewton, and K. A. Magri. 1991. Hormones, growth factors, and myogenic differentiation. Annu. Rev. Physiol. 53:201-216.

Grigsby, M. E., and A. Trenkle. 1986. Plasma growth hormone, insulin, glucocorticoids and thyroid hormones in large, medium and small breeds of steers with and without an estradiol implant. Domest. Anim. Endocrinol. 3:261-267.

Habeeb, A. A. M., I. P. M. Marai, and T. H. Kamal. 1992. Heat stress. Pages 27-47 in Farm Animals and the Environment. C. Phillips and D. Piggins, ed. CABI Publishing, Wallingford, UK.

Hahn, G. L. 1995. Environmental influences on feed intake and performance of feedlot cattle Pages 207-227 in Proc. Symp.: Intake by Feedlot Cattle. Oklahoma State Univ., Publ. no. P-942. F. N. Owens, ed. Oklahoma State Univ., Stillwater.

Hayden, J. M., W. G. Bergen, and R. A. Merkel. 1992. Skeletal muscle protein metabolism and serum growth hormone, insulin, and cortisol concentrations in growing steers implanted with estradiol- $17 \beta$, trenbolone acetate, or estradiol- $17 \beta$ plus trenbolone acetate. J. Anim. Sci. 70:2109-2119.

Hersom, M. J., R. P. Wettemann, C. R. Krehbiel, G. W. Horn, and D. H. Keisler. 2004. Effect of live weight gain of steers during winter grazing: III. Blood metabolites and hormones during feedlot finishing. J. Anim. Sci. 82:2059-2068.

Hunt, D. W., D. M. Henricks, G. C. Skelley, and L. W. Grimes. 1991. Use of trenbolone acetate and estradiol in intact and castrate male cattle: Effects on growth, serum hormones, and carcass characteristics. J. Anim. Sci. 69:2452-2462.

Johnson, B. J., M. E. White, M. R. Hathway, C. J. Christians, and W. R. Dayton. 1998. Effect of combined trenbolone acetate and estradiol implant on steady-state IGF-I mRNA concentrations in the liver of wethers and the longissimus muscle of steers. J. Anim. Sci. 76:491-497.

Kamal, T. H., and I. I. Ibrahim. 1969. The effect of the natural climate of the Sahara and controlled climate on thyroid gland activity in Friesian cattle and water buffaloes. Int. J. Biometeorol. 13:275-285.

Kennedy, P. M., B. A. Young, and R. J. Christopherson. 1977. Studies on the relationship between thyroid function, cold acclimation and retention time of digesta in sheep. J. Anim. Sci. 45:10841090.

Kreikemeier, W. M., and T. L. Mader. 2004. Effects of growth-promoting agents and season on yearling feedlot heifer performance. J. Anim. Sci. 82:2481-2488.

LCI. 1970. Patterns of transit losses. Livestock Conservation Institute, Omaha, NE.

Lee, C. Y., and D. M. Henricks. 1990. Comparisons of various acidic treatments of bovine serum on insulin-like growth factor-I im- munoreactivity and binding activity. J. Endocrinol. 127:139148.

Mader, T. L., J. M. Dahlquist, and J. B. Gaughan. 1997. Wind protection effects and airflow patterns in outside feedlots. J. Anim. Sci. 75:26-36.

Mader, T. L., S. M. Holt, G. L. Hahn, M. S. Davis, and D. E. Spiers. 2002. Feeding strategies for managing heat load in feedlot cattle. J. Anim. Sci. 80:2373-2382.

Marsh, W. H., B. Fingerhut, and H. Miller. 1965. Automated and manual direct methods for the determination of blood urea. Clin. Chem. 11:624-627.

Murphy, T. A., and S. C. Loerch. 1994. Effects of restricted feeding of growing steers on performance, carcass characteristics, and composition. J. Anim. Sci. 72:2497-2507.

National Oceanic and Atmospheric Administration (NOAA). 1976. Livestock hot weather stress. Operations Manual Letter C-3176. NOAA, Kansas City, MO.

NRC. 1996. Nutrient Requirements of Beef Cattle. 7th ed. Natl. Acad. Press, Washington, DC.

Richards, M. W., L. J. Spicer, and R. P. Wettemann. 1995. Influence of diet and ambient temperature on bovine serum insulin-like growth factor-I and thyroxine: Relationships with non-esterified fatty acids, glucose, insulin, luteinizing hormone and progesterone. Anim. Reprod. Sci. 37:267-279.

Sarko, T. A., M. D. Bishop, and M. E. Davis. 1994. Relationship of air temperature, relative humidity, precipitation, photoperiod, wind speed and solar radiation with serum insulin-like growth factor (IGF-I) concentration in Angus beef cattle. Domest. Anim. Endocrinol. 11:281-290.

Stick, D. A., M. E. Davis, S. C. Loerch, and R. C. M. Simmen. 1998. Relationship between blood serum insulin-like growth factor 1 concentration and postweaning feed efficiency of crossbred cattle at three levels of dietary intake. J. Anim. Sci. 76:498-505.

Thom, E. C. 1959. The discomfort index. Weatherwise 12:57-59.

Trenkle, A. 1997. Mechanisms of action of estrogens and androgens on performance of cattle - Hormonal basis. Pages 15-22 in Proc. Symp: Impact of Implants on Performance and Carcass Value of Beef Cattle. Oklahoma Agric. Exp. Sta. Publ. No. P-957. Oklahoma State Univ., Stillwater.

US National Weather Service. 2005. Wind Chill Chart. http://observe.arc.nasa.gov/nasa/earth/wind_chill/chill_applet.html

Webster, A. J. 1973. Heat loss from cattle with particular emphasis on the effects of cold. Pages 205-231 in Heat Loss from Animals and Man: Assessment and Control. J. L. Monteith and L. B. Mount, ed. Butterworths, London, UK.

Westra, R., and R. J. Christopherson. 1976. Effects of cold on digestibility, retention time of digesta, reticulum motility and thyroid hormones in sheep. Can. J. Anim. Sci. 56:699-708.

Yousef, M. K., and H. D. Johnson. 1985. Endocrine systems and thermal environment. Pages 133-141 in Stress Physiology in Livestock: Basic Principles. CRC Press Inc., Boca Raton, FL. 